\title{
Cerebral malaria: gamma-interferon redux
}

\section{Nicholas H. Hunt ${ }^{1 *}$, Helen J. Ball' , Anna M. Hansen ${ }^{1+}$, Loke T. Khaw ${ }^{1 t}$, Jintao Guo ${ }^{1}$, Supun Bakmiwewa ${ }^{1}$, Andrew J. Mitchell', Valéry Combes ${ }^{2}$ and Georges E. R. Grau ${ }^{2}$}

${ }^{1}$ Molecular Immunopathology Unit, School of Medical Sciences and Bosch Institute, University of Sydney, Sydney, NSW, Australia

${ }^{2}$ Vascular Immunology Unit, School of Medical Sciences and Bosch Institute, University of Sydney, Sydney, NSW, Australia

\section{Edited by:}

Samuel C. Wassmer, New York

University School of Medicine, USA

\section{Reviewed by:}

Kendall A. Smith, Weill Medical

College of Cornell University, USA

Danny Arnold Milner Jr, Brigham

and Women's Hospital, USA

\section{${ }^{*}$ Correspondence:}

Nicholas H. Hunt, Molecular

Immunopathology Unit, University

of Sydney, Medical Foundation

Building (K25), Sydney, NSW 2006,

Australia

e-mail: nicholas.hunt@sydney.edu.au

tPresent address:

Anna M. Hansen, Department of

Respiratory, Inflammation and

Autoimmunity, Medlmmune,

Gaithersburg, USA;

Loke T. Khaw, Department of

Parasitology, Faculty of Medicine,

University of Malaya, Kuala Lumpur,

Malaysia
There are two theories that seek to explain the pathogenesis of cerebral malaria, the mechanical obstruction hypothesis and the immunopathology hypothesis. Evidence consistent with both ideas has accumulated from studies of the human disease and experimental models. Thus, some combination of these concepts seems necessary to explain the very complex pattern of changes seen in cerebral malaria. The interactions between malaria parasites, erythrocytes, the cerebral microvascular endothelium, brain parenchymal cells, platelets and microparticles need to be considered. One factor that seems able to knit together much of this complexity is the cytokine interferon-gamma (IFN- $\gamma$ ). In this review we consider findings from the clinical disease, in vitro models and the murine counterpart of human cerebral malaria in order to evaluate the roles played by IFN- $\gamma$ in the pathogenesis of this often fatal and debilitating condition.

Keywords: interferon-gamma, cerebral malaria, platelets, microparticles, immunopathology, $\mathrm{CD}^{+} \mathrm{T}_{\text {lymphocyte, }}$ blood-brain barrier, kynurenine pathway

\section{SCOPE}

It is 25 years since the first demonstration that the proinflammatory cytokine interferon- $\gamma$ (IFN- $\gamma$ ) drives the pathogenesis of experimental cerebral malaria (Grau et al., 1989). It therefore seems appropriate to revisit this topic and evaluate progress in our understanding of the mechanisms involved, as well as their significance for the pathogenesis of this lifethreatening (Molyneux et al., 1989; Newton et al., 2000) and disabling (Molyneux et al., 1989; Kihara et al., 2006; John et al., 2008) condition in human beings.

The production of IFN- $\gamma$ in humans and mice occurs as part of anti-malarial immunity. This role of the cytokine has been reviewed recently (McCall and Sauerwein, 2010) and will not be discussed here. Although IFN- $\gamma$ also has been shown to play an essential role in the pathogenesis of some other infectious diseases that adversely affect the central nervous system (CNS), such as pneumococcal meningitis (Mitchell et al., 2012), we here will focus on the cerebral manifestations of severe malaria caused by Plasmodium falciparum ( $P f$ ). Furthermore, we will not deal with the possible roles of the Type I interferons in cerebral malaria (Vigario et al., 2007; Morrell et al., 2011; Ball et al., 2013; Palomo et al., 2013).

\section{INTERFERON- $\gamma$}

The IFN- $\gamma$ gene was cloned in 1982, though knowledge of the existence of IFN- $\gamma$-like biological activity dates back a further two decades (Billiau and Matthys, 2009). The cytokine has a molecular weight of $45 \mathrm{kDa}$ and its gene is located on chromosome 12 in humans and 10 in mice. It has an enormous range of actions upon many cell types, in particular those involved in immunity, both innate and adaptive, and inflammation. The IFN- $\gamma$-producing cells of particular relevance to malaria include $\mathrm{CD} 4^{+}, \mathrm{CD} 8^{+}$, and $\gamma \delta \mathrm{T}$ lymphocytes, and Natural Killer (NK) cells.

IFN- $\gamma$ signaling pathways have been well-characterized. The IFN- $\gamma$ receptor is composed of two chains and binding of the cytokine leads to recruitment of the tyrosine kinases JAK1 and JAK2. This leads to activation of STAT1, which homodimerizes, enters the nucleus and initiates the transcription of Interferon Response Factors that induce the expression of a wide range of genes (Schroder et al., 2004; Saha et al., 2010). Other signal transduction pathways can be triggered by IFN- $\gamma$, and the actions of the cytokine are negatively modulated by suppressor of cytokine signaling proteins (Saha et al., 2010). Recombinant IFN- $\gamma$ and adenovirus vectors that express IFN- $\gamma$ cDNA have been trialed clinically, with some success, for a range of diseases including chronic granulomatous disease, hepatitis, tuberculosis, and certain cancers (see Miller et al., 2009 for review). Antibodies that neutralize the cytokine's actions have been used to treat rheumatoid arthritis and multiple sclerosis (Miller et al., 2009).

Malaria immunity involves both the innate and adaptive immune systems (Good et al., 2005; Riley et al., 2006). Pro-inflammatory cytokines, in particular IFN- $\gamma$, drive the 
cell-mediated immune response that controls parasite numbers early in the intraerythrocytic cycle, and antibody seems to be responsible for "mopping up" and preventing recrudescence (Good et al., 2005; Riley et al., 2006; McCall and Sauerwein, 2010).

\section{SEVERE MALARIA}

Severe malaria is a set of systemic complications associated with $P f$ infection that includes cerebral malaria, which is involved in a high proportion of fatal cases, particularly in African children. This acute brain dysfunction leads to coma and, in the absence of anti-malarial therapy, death. Fortunately, this occurs in only a small percentage of $P f$ infections. Nevertheless, long-term neurological sequelae occur in a substantial proportion of those who survive pediatric cerebral malaria (Molyneux et al., 1989; Kihara et al., 2006; John et al., 2008).

Histopathological observations and other evidence have established that hemorrhage, sequestration of parasitized red blood cells (PRBC) and leukocytes, and increased blood-brain barrier permeability occur in both human and murine cerebral malaria (Toro and Roman, 1978; Thumwood et al., 1988; Das et al., 1991; Chan-Ling et al., 1992; Patnaik et al., 1994; Turner et al., 1994; Brown et al., 1999a, 2001; White et al., 2001; van der Heyde et al., 2001; Adams et al., 2002; Grau et al., 2003; Hunt and Grau, 2003; Taylor et al., 2004; Amante et al., 2010; Claser et al., 2011; Cunnington et al., 2013). Examples of these phenomena from the experimental model are shown in Figures 1-3.

Two mechanisms are considered to be important in CM pathogenesis: microvascular obstruction leading to hypoxia, and
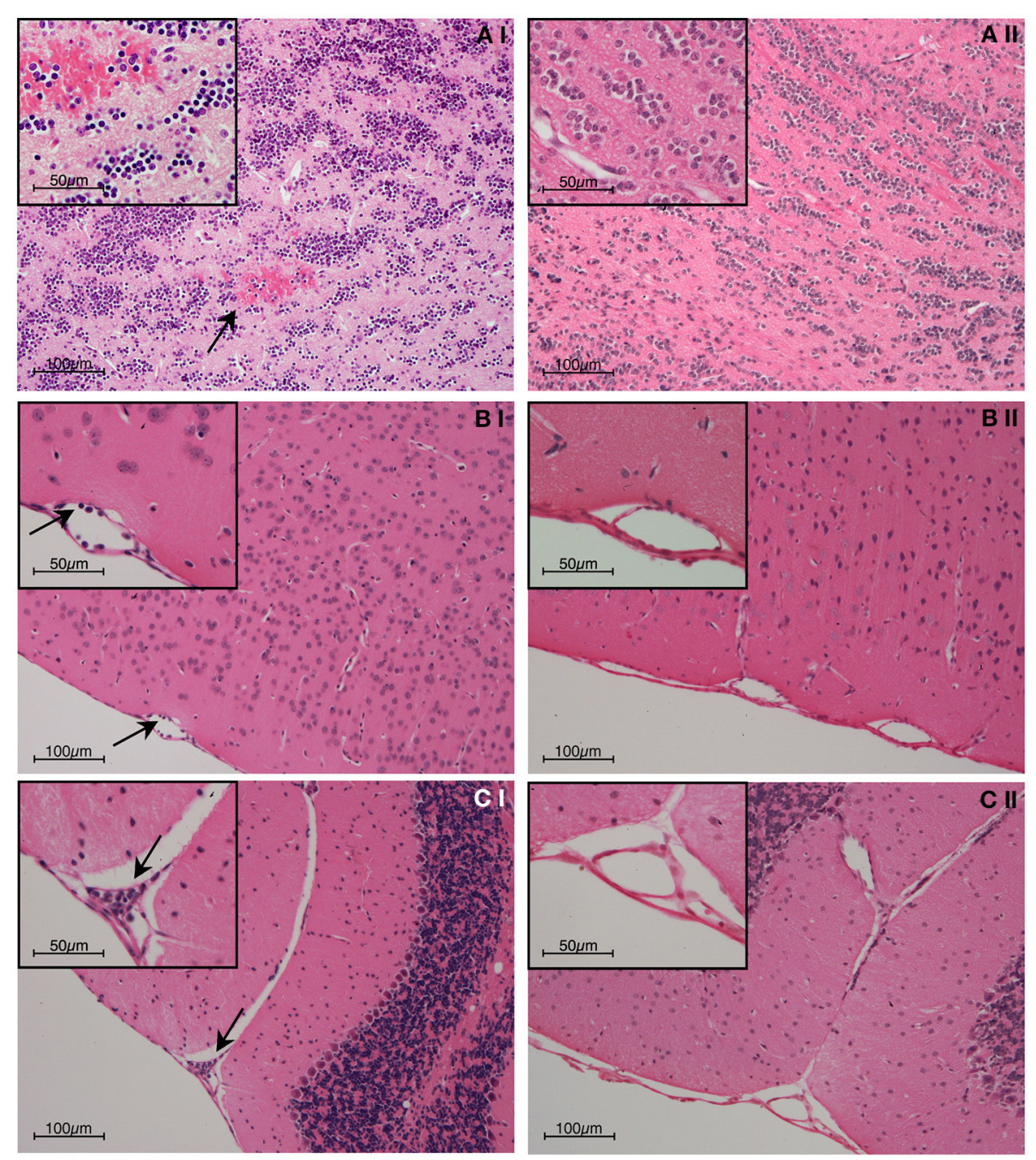

FIGURE 1 | Representative post-mortem histopathology findings in $\mathbf{H}$ \& $E$ stained brain sections from (i) wild-type and (ii) IFN- $\gamma^{-/-}$ C57BL/6 mice on day 6 post-inoculation with $1 \times 10^{6}$ PbA-PRBC. As no difference was evident between uninfected mice and infected IFN- $\gamma^{-/-}$mice, only the latter are shown. (A) Olfactory bulb; (B) Meningeal vessel; (C) Cerebellum. The brains of PbA-infected w/type

mice showed hemorrhage and leukocyte adhesion to the cerebral vasculature (arrows), whereas no pathological findings were evident in any IFN- $\gamma^{-1-}$ mouse. In this and later Figures (where appropriate) the work was carried out according to national and State legislation on animal experimentation, with approval from the University of Sydney Animal Ethics Committee. 

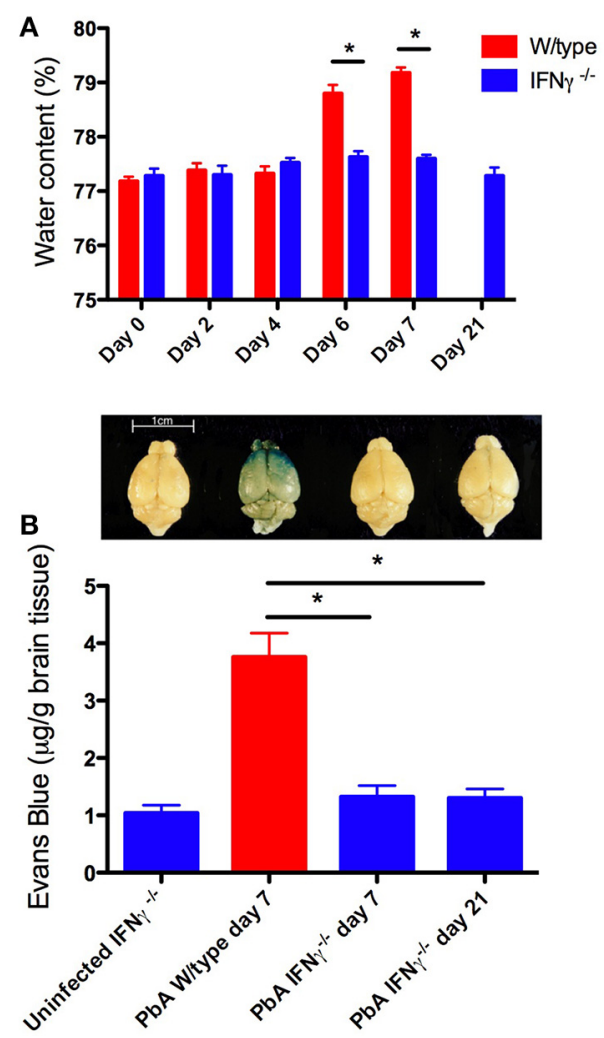

FIGURE 2 | Brain edema and blood-brain barrier compromise after $\mathbf{P b A}$ infection. Water content was calculated from wet and dry weight. Evans blue, a dye that binds to circulating albumin, was injected intravenously $2 \mathrm{~h}$ before mice were euthanased; the brain was perfused with saline, removed, photographed, and water-extracted; the Evans blue content was measured spectrophotometrically at $510 \mathrm{~nm}$. (A) PbA-infected wild-type mouse brains had significantly greater water content compared with infected IFN- $\gamma^{-/-}$mice at days 6 and 7 post-inoculation $\left({ }^{*} p<0.001\right.$, Two-Way ANOVA with Bonferroni post-test). (B) PbA-infected wild-type mice had significantly greater extravasation of Evans Blue dye into the brain parenchyma on day 7 post-inoculation compared to infected IFN- $\gamma^{-/-}$mice on day 7 or 21 post-inoculation ${ }^{*} p<0.001$, One-Way ANOVA with Bonferroni post-test). Above each bar of the graph is shown a representative brain from that experimental group. Columns and vertical bars are mean \pm s.e.m. ( $n=5$ per group).

immunopathological processes. Although some proponents of the former mechanism discount the latter (White et al., 2013), many researchers in the field consider that a combination of these two best explains the outcomes of many published clinical, pathological, experimental and genetic investigations of cerebral malaria (Grau and De Kossodo, 1994; Hunt and Grau, 2003; Mackintosh et al., 2004; Cunnington et al., 2013).

Microvascular obstruction in the brain occurs in human cerebral malaria. This is thought to be a consequence of binding of $P f$-parasitized erythrocytes ( $P f$-PRBC) to the vascular endothelium through a parasite-encoded protein, $P f E M P 1$, that can interact with a number of adhesion molecules (Warrell et al., 1988; Berendt et al., 1994; Turner et al., 1994, 2013). Accumulation of $P f$-PRBC in brain microvessels is characteristic of pediatric (Taylor et al., 2004) and adult (Ponsford et al., 2012) cerebral malaria victims, with leukocytes also being present (Patnaik et al., 1994; Grau et al., 2003; Taylor et al., 2004; Armah et al., 2005), and is accompanied by lactate accumulation in the cerebrospinal fluid (CSF) (White et al., 1985; Warrell et al., 1988; Molyneux et al., 1989), consistent with the suggestion that oxygen supply to the brain is compromised.

Microvascular obstruction (Chan-Ling et al., 1992), hypoxia (Hempel et al., 2011) and accumulation of lactate in the CNS (Sanni et al., 2001; Rae et al., 2004) also occur in experimental cerebral malaria $[P$. berghei ANKA (PbA) infection in mice]. Reduced blood flow and metabolic changes consistent with hypoxia also have been identified in this mouse model using multimodal magnetic resonance (Penet et al., 2005). The cause of vascular obstruction in murine cerebral malaria has not been established, though leukocytes and PbA-PRBC accumulate in the CNS microcirculation (Thumwood et al., 1988; Chan-Ling et al., 1992; Amante et al., 2007; Miu et al., 2008a; Nie et al., 2009; Ampawong et al., 2014).

Thus, a hypoxic metabolic profile and accumulation of PRBC and leukocytes in the cerebral microcirculation are features of both human and experimental CM. One of the great, unanswered questions is why vascular obstruction does not lead to catastrophic neuronal damage, as it does in stroke. One possibility is that any occlusive events and ischemia are very short-lived, which is difficult to test. Another is that the hypoxic metabolic profile is also influenced by processes independent of vascular obstruction, such as the actions of cytokines (Rae et al., 2004; Parekh et al., 2006).

Administration of an IFN- $\gamma$-neutralizing antibody led to the concept that this cytokine is a key contributor to the pathogenesis of cerebral malaria in the PbA model (Grau et al., 1989). This finding subsequently was confirmed with IFN- $\gamma$ gene knockout (GKO) (Yanez et al., 1996; Sanni et al., 1998; Belnoue et al., 2008) and IFN- $\gamma$ receptor GKO (Amani et al., 2000) mice. There is substantial evidence implicating other pro-inflammatory cytokines in the pathogenesis of cerebral malaria, both human and experimental (Clark and Rockett, 1994; Udomsangpetch et al., 1997; Brown et al., 1999b; Engwerda et al., 2002; Hunt and Grau, 2003; Schofield and Grau, 2005; Hunt et al., 2006). Human genetic association studies have demonstrated links between immune cell products and susceptibility to human cerebral malaria (Kwiatkowski, 2005; Verra et al., 2009). Antiinflammatory molecules or processes, such as interleukin (IL)-10 (de Kossodo et al., 1997; Ho et al., 1998a), transforming growth factor- $\beta$ (Omer and Riley, 1998; Riley et al., 2006) and regulatory T cells (Nie et al., 2007), appear to be important in malaria for "damping down" innate immune responses and channeling the development of effective adaptive immunity.

Interaction between microvascular obstruction and immunopathology might occur in a number of ways. First, pro-inflammatory cytokines, including IFN- $\gamma$, induce the expression on endothelial cells of adhesion molecules (Wahl et al., 1996; Weiser et al., 2007), which are capable of mediating Pf-RBC and leukocyte interactions with the endothelium (Wahl et al., 1996; Ho et al., 1998b). Indeed, IFN- $\gamma$ and lymphotoxin $\alpha$, the two key pathogenetic cytokines in experimental cerebral malaria (Grau et al., 1989; Engwerda et al., 2002), are strongly 

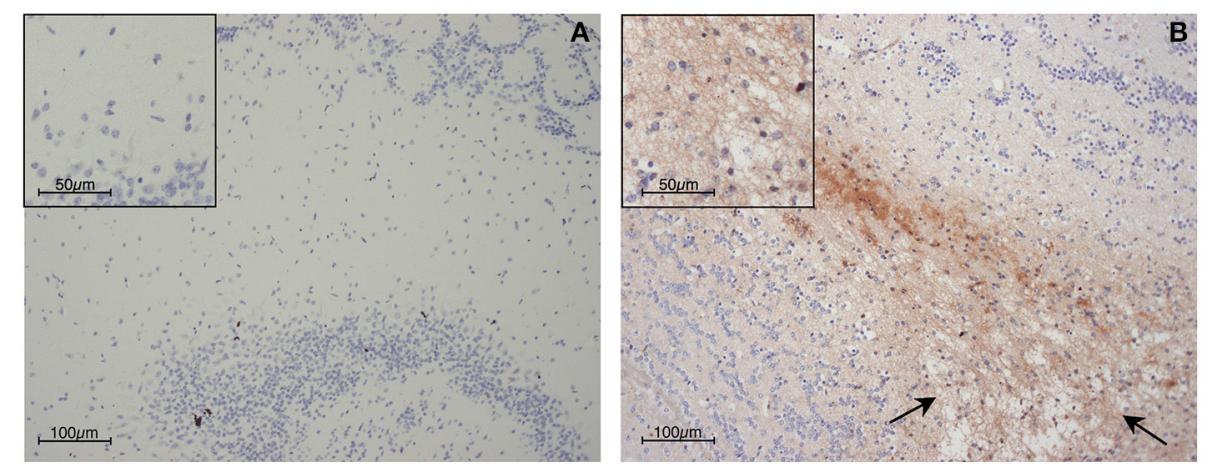

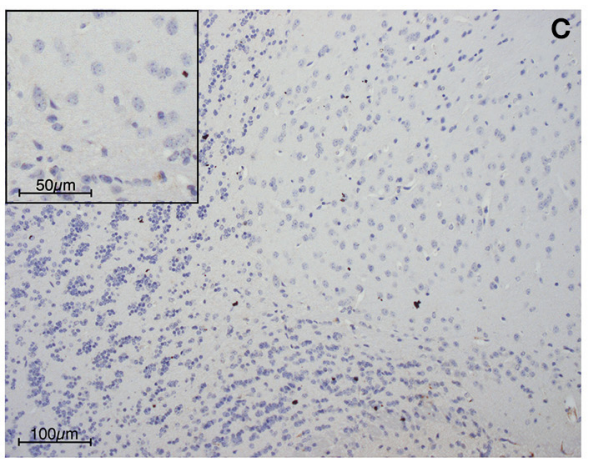

FIGURE 3 | Blood-brain barrier compromise during PbA infection, as determined by immunohistochemical detection of fibrinogen within the parenchyma of the olfactory bulb. (A) Uninfected control mouse; (B) $\mathrm{PbA}$-infected wild-type mouse at day 6 post-inoculation; (C) PbA-infected

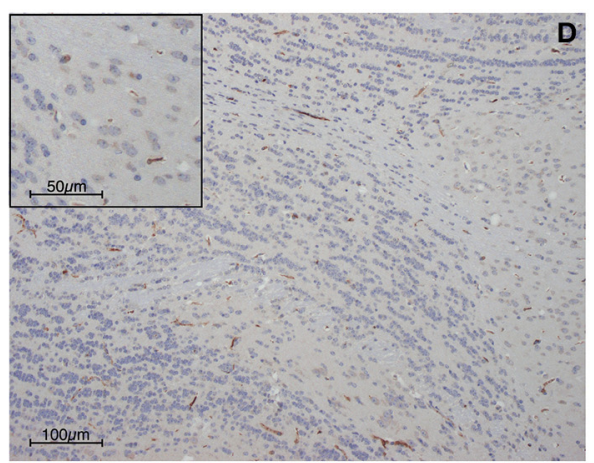

IFN- $\gamma^{-/-}$mouse at day 6 post-inoculation and (D) day 20-22 post-inoculation Blood-brain barrier permeabilization to protein is clearly evident within the wild-type mouse, in which edematous changes also can be seen (arrows). These changes were not seen in IFN- $\gamma^{-/-}$mice at any stage of infection. synergistic in inducing the expression of vascular cell adhesion molecule-1, intercellular adhesion molecule-1 (ICAM-1) and E-selectin in mouse brain endothelial cells in vitro (Weiser et al., 2007). Expression of these adhesion molecules on the cerebral microvascular endothelium has been reported in human and murine cerebral malaria (de Kossodo and Grau, 1993; Turner et al., 1994; Bauer et al., 2002; Armah et al., 2005) and ICAM-1 GKO mice are protected against $\mathrm{PbA}$-induced cerebral malaria (Favre et al., 1999).

Second, the accumulation of PRBC and leukocytes in the cerebral microcirculation favors their interaction and might serve to focus the production of immune/inflammatory products, such as pro-inflammatory cytokines, in that critical location (Khaw et al., 2013). This setting has been modeled in vitro using co-cultures of mouse (El-Assaad et al., 2013) and human (Wassmer et al., 2004, 2006a,b) brain endothelial cells and PRBC. Here, cytokines, including IFN- $\gamma$, tumor necrosis factor (TNF) and lymphotoxin $\alpha$, lead to endothelial cell activation resulting in the local binding of platelets, which, in turn, enhances endothelial activation and apoptosis (Wassmer et al., 2006a,b) (Figure 4), as discussed in more detail below.

Finally, we recently have proposed that the effects of hypoxia and cytokines might intersect at key locations in the pathogenesis of cerebral malaria, namely endothelial cells and astrocytes (Combes et al., 2012), which are key components of the neurovascular unit. Astrocytes influence the functions of all CNS cells and have unique features that make them a strong candidate to be a convergence point of ischemia and immunopathology in the events leading to cerebral malaria (Combes et al., 2012). They control the extracellular milieu of the CNS, modulate synaptic transmission, act as a bioenergetic regulator and influence vascular properties, including blood-brain barrier integrity and blood flow. Their central roles in these vital functions mean that astrocytes often are a major determinant of the outcome of several diseases that affect the CNS (Verkhrasky et al., 2009). For example, in stroke, obstruction of an artery prevents oxygen and glucose delivery to the downstream tissue. In the core of the ischemic region, where the supply deficit is most severe, astrocytes and neurons perish through a network of interrelated processes, many of which are due to severe loss of intracellular ATP (Rossi et al., 2007). Surrounding this core is the hypoperfused penumbral region, in which cellular ATP is less compromised. It is now believed that astrocytes hold the key to whether neurons die, or regain function, in the penumbral region in stroke (Nedergaard and Dirnagl, 2005; Panickar and Norenberg, 2005; Trendelenburg and Dirnagl, 2005; Takano et al., 2009). It is possible that they have similar significance in cerebral malaria, where the occurrence of neuronal damage has been reported (Medana et al., 2002, 2007).

Astrocytes are target cells of IFN- $\gamma$, with outcomes such as astrogliosis and production of chemokines (John et al., 2003; Liberto et al., 2004). Changes in astrocyte morphology and function occur early in the course of experimental cerebral malaria (Medana et al., 1996), as visualized in retinal 

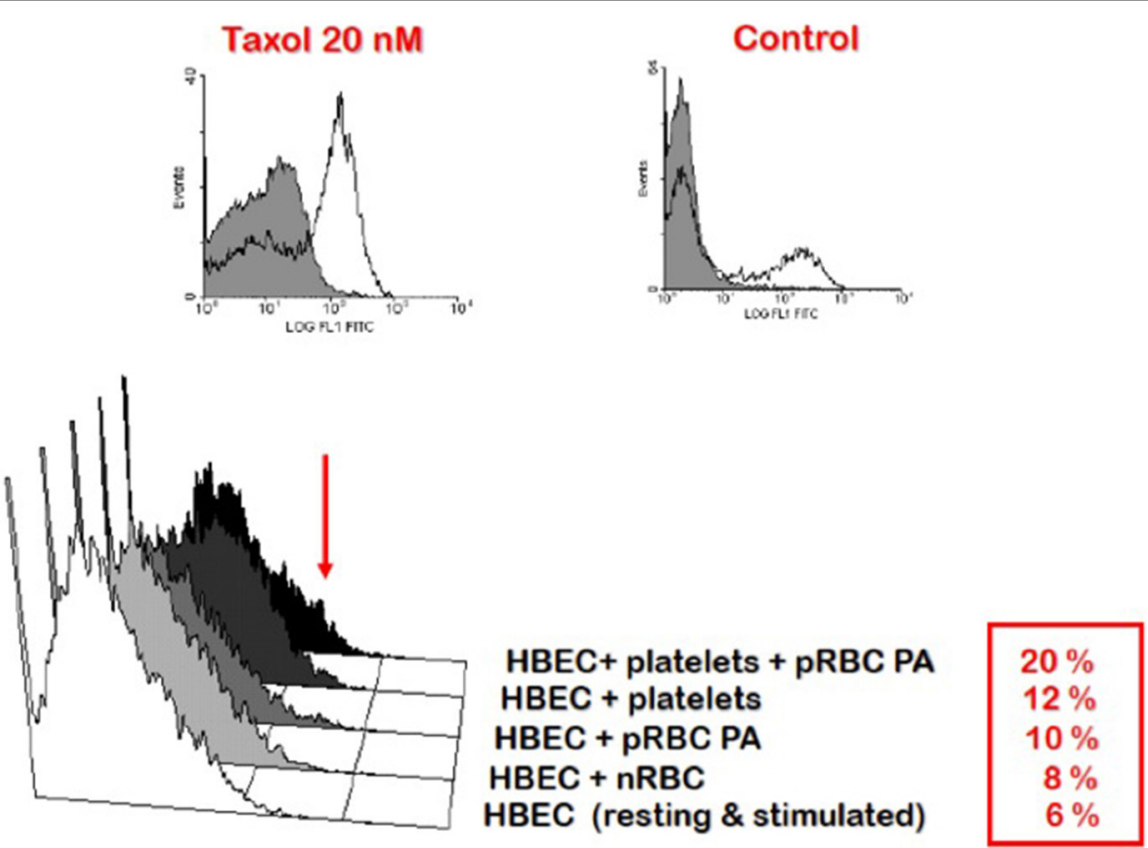

FIGURE 4 | Enhancement of platelet-mediated endothelial cell apoptosis after IFN- $\boldsymbol{\gamma}$ stimulation. HBEC were stimulated with IFN- $\gamma$ overnight prior to addition of platelets and RBC. Taxol treatment of HBEC was used as the positive control. FITC-BrdU nuclear fragmentation was quantified using the APO-Direct Kit (BD Biosciences) and an EPICS-XL flow cytometer (Beckman-Coulter). Results are expressed as percentages of cells undergoing apoptosis. HBEC, human brain endothelial cells; nRBC, normal red blood cells; pRBC, parasitized red blood cells; PA, Palo Alto strain of Plasmodium falciparum. In this and later Figures (where appropriate) the work was carried out according to national and State legislation on human experimentation, with approval from the University of Sydney Human Ethics Committee. wholemounts. The retina parallels the pathological changes in the brain in both human and experimental cerebral malaria (ChanLing et al., 1992; White et al., 2009), and retinal changes have considerable diagnostic and pathophysiological significance in the human condition (Beare et al., 2004; White et al., 2009; Birbeck et al., 2010). Astrogliosis in murine malaria is seen in cerebral malaria but not in severe anemia (Medana et al., 1996; Ampawong et al., 2014). Accompanying this astrocyte activation is production of CXCL10 (Miu et al., 2008a). Morphological changes in astrocytes have been reported in the brain and retina in human severe malaria (Medana et al., 2002; White et al., 2009), which, by analogy with other CNS diseases (Panickar and Norenberg, 2005; Rossi and Volterra, 2009), could be in part a response to the occurrence of neuronal damage. Local production of cytokines and a hypoxic environment also might play a role, as discussed above.

Endothelial cells are another pivotal cell type that affects the CNS in infectious diseases (Combes et al., 2012). The endothelium becomes activated in cerebral malaria and its roles include the expression of adhesion molecules (de Kossodo and Grau, 1993; Turner et al., 1994; Favre et al., 1999; Bauer et al., 2002; Armah et al., 2005), production of chemokines (Miu et al., 2008a), release of microparticles (Combes et al., 2006, 2010), generation of pro-coagulant factors (Grau et al., 1997) and interactions with platelets (Lou et al., 1997; Wassmer et al., 2006a) (Figure 4). Several of these processes are stimulated by IFN- $\gamma$, and endothelial dysfunction is induced by hypoxia in other conditions (Jelic and Le Jemtel, 2008). Hypoxia/reoxygenation was found to dramatically enhance the stimulatory effect of TNF on ICAM-1 upregulation in human brain microvascular endothelial cells (Figure 5).

Thus, the activities of astrocytes and endothelial cells are influenced by both pro-inflammatory cytokines and hypoxia, processes that are widely considered to be relevant in the context of cerebral malaria.

\section{SOURCE OF IFN- $\gamma$ IN SEVERE MALARIA}

In human volunteers infected with $P f$ sporozoites, IFN- $\gamma$ is initially detectable at around one to two days after initiation of blood stage infection (Walther et al., 2006). These processes have been modeled in vitro using co-culture of Pf-PRBC and human peripheral blood mononuclear cells (HPBM) from malaria-naïve donors. In this system, IFN- $\gamma$ is produced with similar kinetics to that seen in vivo (Artavanis-Tsakonas and Riley, 2002). Some studies have argued that $\gamma \delta \mathrm{T}$ cells expressing NK cell receptors may be the dominant source of IFN- $\gamma$ (Hensmann and Kwiatkowski, 2001; D’Ombrain et al., 2007). However, substantial evidence supports a model in which the parasite is initially sensed by myeloid cells, which in turn stimulate NK cells to produce IFN- $\gamma$ via contact and cytokine signals (Artavanis-Tsakonas and Riley, 2002; Baratin et al., 2005; Korbel et al., 2005; Newman et al., 2006). Following this initial production of IFN- $\gamma$ by NK cells (within the first $24 \mathrm{~h}$ in culture), $\alpha \beta \mathrm{T}$ cells may then dominate the IFN- $\gamma$ response (Horowitz et al., 2010). In vivo, some leukocyte- $P f$-iRBC interactions may take place in the cerebral microcirculation and, interestingly, IFN- $\gamma$ expression by HPBM 


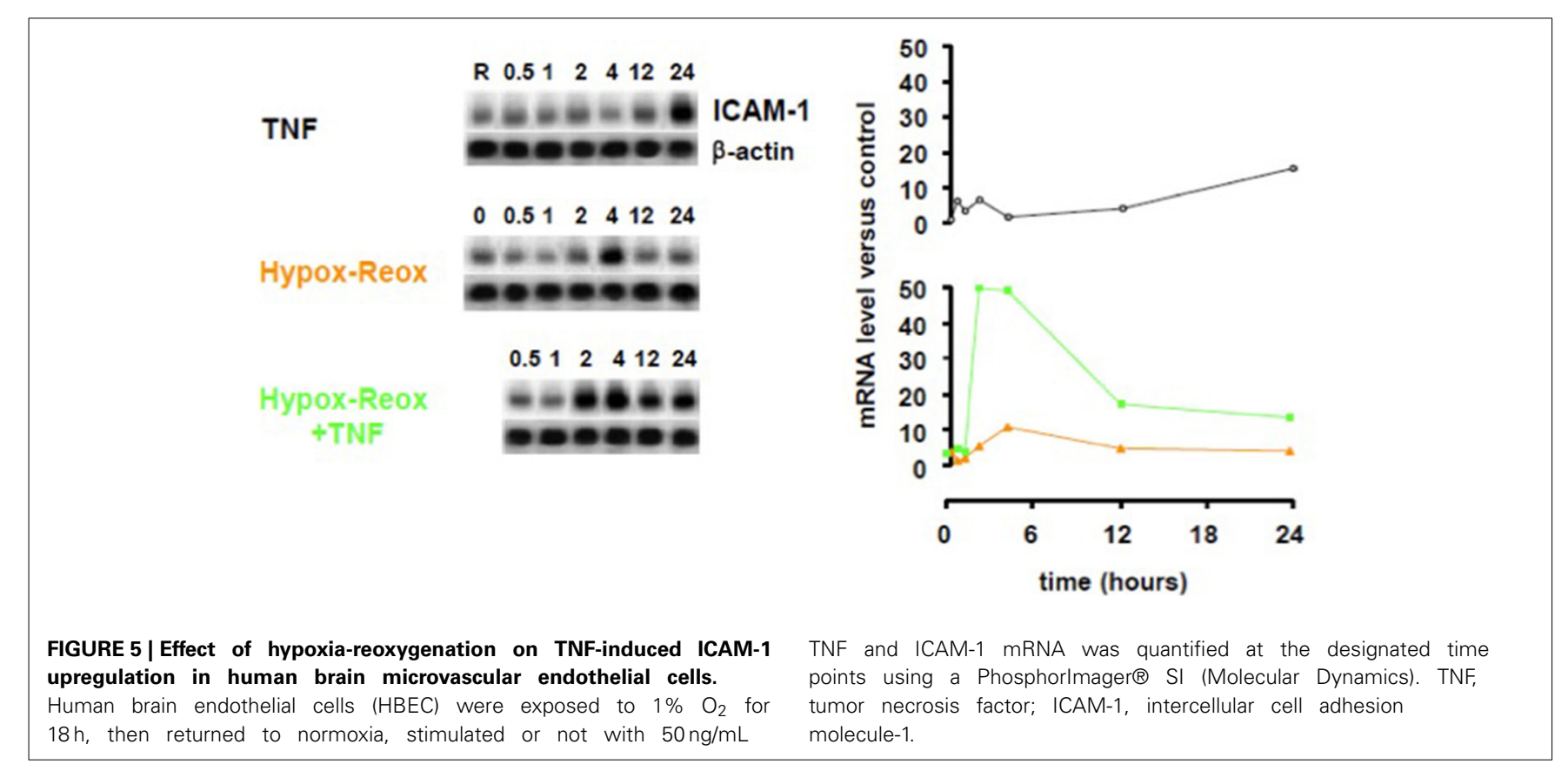

is substantially enhanced when co-cultured with $P f$-PRBC in the presence of brain endothelial cells (Khaw et al., 2013), a process that requires the presence of NK cells.

In experimental murine cerebral malaria the relative contribution of different cell subsets to levels of circulating IFN- $\gamma$ is largely dependent upon on the stage of infection. Serum levels of IFN- $\gamma$ at times prior to development of the cerebral complications are at least partially under the control of genes in the Natural Killer Complex loci, which suggests that early IFN- $\gamma$ derives from either NK or NKT cells (Hansen et al., 2003, 2005, 2014). This early production of IFN- $\gamma$ by NK cells is dependent upon IL12 from dendritic cells (Ryg-Cornejo et al., 2013). Use of IFN $\gamma$ reporter mice reinforced that such production was largely from NK cells, whereas at late stages of infection, immediately prior to and during neurological disease, $\mathrm{CD}^{+}{ }^{+}$and $\mathrm{CD} 8^{+} \mathrm{T}$ cells are the predominant sources (Villegas-Mendez et al., 2012).

\section{TARGETS AND CONSEOUENCES OF IFN $-\gamma$ IN CEREBRAL MALARIA}

In addition to systemic production of IFN- $\gamma$, in the experimental model IFN $-\gamma$ mRNA is strongly expressed in brain homogenates late in the course of $\mathrm{PbA}$ infection, with differences of degree between various brain regions (Figure 6). The IFN- $\gamma$ receptor is widely expressed throughout the hemopoetic, cardiovascular and CNSs, providing many targets for this cytokine in cerebral malaria (Figure 7). Many cell populations that have been implicated in the pathogenesis of the condition may respond to IFN- $\gamma$, for example various types of leukocytes, endothelial cells and brain parenchymal cells such as astrocytes and microglia. These have been extensively studied in model systems, both in vivo and in vitro. For obvious reasons this type of intervention-driven hypothesis testing is impossible in human cerebral malaria, which sometimes has led to skepticism about the roles of IFN- $\gamma$ and other cytokines in the human disease. Of course, this caveat applies equally to every other hypothesis about the pathogenesis of severe malaria. Gene expression analysis in experimental cerebral malaria has revealed the induction of many IFN- $\gamma$-dependent genes in the CNS (Lovegrove et al., 2007; Miu et al., 2008b) and an equivalent post-mortem study in the human condition is a worthwhile goal.

During $\mathrm{PbA}$ infection, current evidence supports a model in which recruitment of leukocytes, in particular $\mathrm{CD}^{+} \mathrm{T}$ cells, by IFN- $\gamma$-dependent processes is a key outcome. Blood-brain barrier compromise in experimental cerebral malaria clearly is driven by IFN- $\gamma$ since it is greatly attenuated in GKO animals (Figures 1-3). Importantly, coincident accumulation of PbA-PRBC and $\mathrm{CD}^{+} \mathrm{T}$ cells is essential for pathogenesis (McQuillan et al., 2011). IFN$\gamma$ drives sequestration of both PbA-PRBC (Amante et al., 2010; Claser et al., 2011) and $\mathrm{CD}^{+} \mathrm{T}$ cells (Belnoue et al., 2008; Miu et al., 2008a) in the brain microvasculature. Although leukocytes are commonly found within cerebral microvessels in human and experimental cerebral malaria, there is little entry into the brain parenchyma. However, this is still a form of inflammation, albeit intravascular rather than intratissular. Signals originating within the parenchyma that impact upon immune and inflammatory cells include CXCL10 production by astrocytes (Miu et al., 2008a), as discussed below.

Both $\mathrm{CD}^{+}$and $\mathrm{CD}^{+} \mathrm{T}$ lymphocytes play obligatory roles in experimental cerebral malaria (Grau et al., 1986; Yanez et al., 1996; Belnoue et al., 2002; Villegas-Mendez et al., 2012). Parasite antigen-specific $\mathrm{CD}^{+}$cytotoxic lymphocytes are generated in murine cerebral malaria (Lau et al., 2011), possibly through interactions with Clec9A dendritic cells (deWalick et al., 2007; Lundie et al., 2008; Piva et al., 2012). CD8 ${ }^{+}$T cells recruited to the brain microvasculature in this system do not carry out their pathogenetic function through IFN- $\gamma$ production (Villegas-Mendez et al., 2012). Instead, there is good evidence supporting cross-presentation of malaria antigens on CNS 


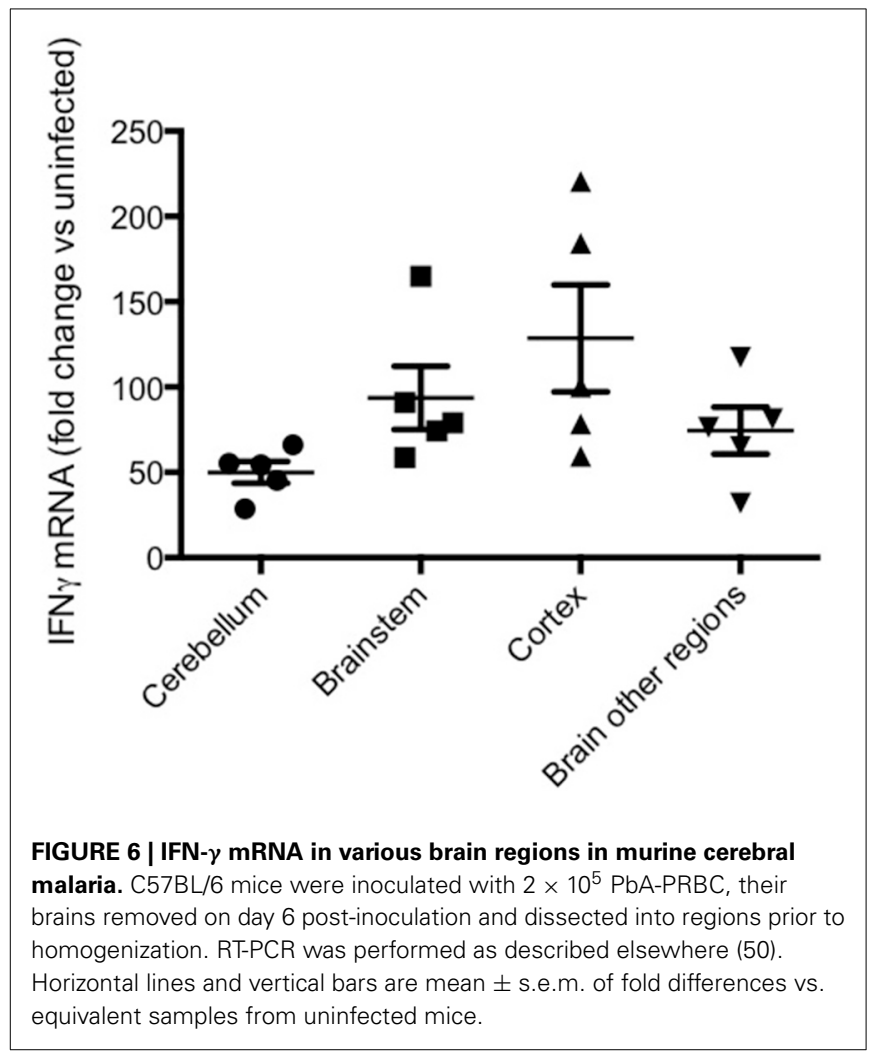

PRBC sequestration $\quad \mathrm{CD}^{+} \mathrm{T}$ cell accumulation

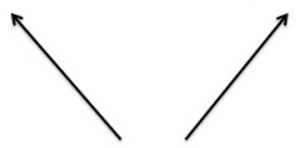

BBB $\longleftarrow$ IFNy $\longleftrightarrow$ endothelial activation

permeabilisation

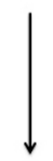

astrocyte activation

FIGURE 7 | Summary of processes relevant to cerebral malaria that are stimulated by IFN- $\gamma$, as derived from experimental models. PRBC,

parasitized red blood cell; BBB, blood-brain barrier.

microvascular endothelial cells (Howland et al., 2013) and recognition by $\mathrm{CD}^{+}$cytotoxic lymphocytes leading to endothelial damage in a perforin- and granzyme B-dependant manner (Potter et al., 1999, 2006; Nitcheu et al., 2003; Haque et al., 2011). This may be the basis of the compromised blood-brain barrier described earlier.

IFN- $\gamma$ is essential for accumulation of $\mathrm{CD}^{+} \mathrm{T}$ cells within the brain microvessels during experimental cerebral malaria (Belnoue et al., 2008). IFN- $\gamma$ produced prior to end stage disease drives production of the CXCR3-binding chemokines CXCL9 and CXCL10 (Campanella et al., 2008; Miu et al., 2008a). There is strong evidence that CXCL9 or CXCL10 and their receptor

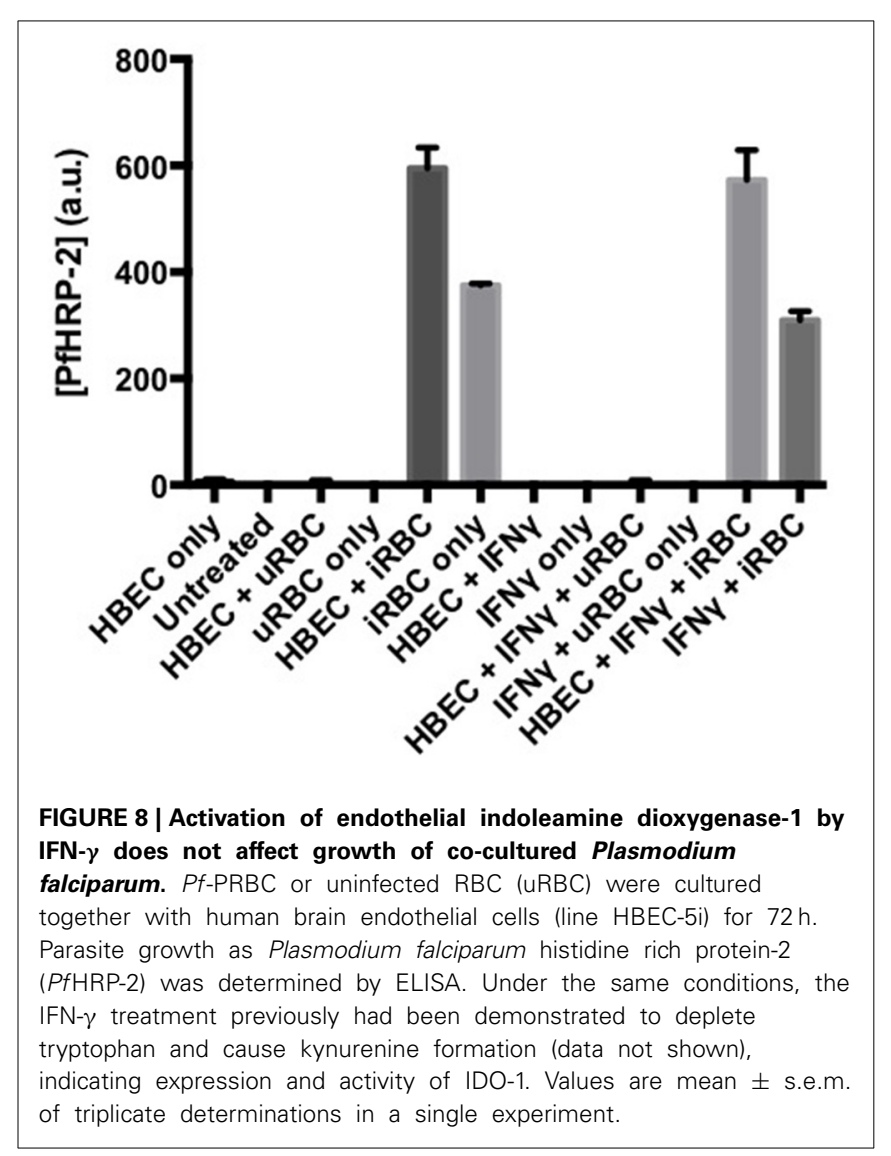

CXCR3 are required for the development of murine cerebral malaria (Belnoue et al., 2008; Campanella et al., 2008; Van den Steen et al., 2008; Miu et al., 2008a; Nie et al., 2009). NK cells localize to the brain vasculature from around day 4 post-infection and can mediate sequestration of $\alpha \beta T$ cells in an IFN- $\gamma$ - and CXCR3-dependent manner (Hansen et al., 2007). Alternatively, adoptive transfer studies using IFN $\gamma$-deficient recipients have suggested that IFN- $\gamma$ produced by $\mathrm{CD} 4{ }^{+} \mathrm{T}$ cells is the dominant source of IFN- $\gamma$ that is involved in induction of CXCR3 ligands, $\mathrm{CD}^{+} \mathrm{T}$ cell sequestration and development of clinical disease (Villegas-Mendez et al., 2012). Importantly, higher plasma and CSF levels of CXCL10 are seen in Ghanaian children with cerebral malaria, compared to those with severe malaria and non-malaria cases (Armah et al., 2007). Furthermore, polymorphisms in the human CXCL10 gene that affect plasma CXCL10 correlate with the incidence of cerebral malaria, particularly in males, in a manner consistent with the data from the experimental studies in mice (Wilson et al., 2013). Thus, this IFN- $\gamma$-regulated chemokine appears to be involved in the disease process in both human and murine cerebral malaria.

The effects of IFN- $\gamma$ have been studied in endothelial cellplatelet-PRBC co-cultures, which involved the human brain microvascular endothelial cell line 5i, human platelets from normal donors and the Palo-Alto (PA) strain of Pf (Wassmer et al., 2006a). While TNF is only able to upregulate ICAM-1, VCAM-1, and CD40 on endothelial cells, IFN- $\gamma$ also induces CD36 upregulation (Petzelbauer et al., 1993). As shown in Figure 4, IFN- $\gamma$ 


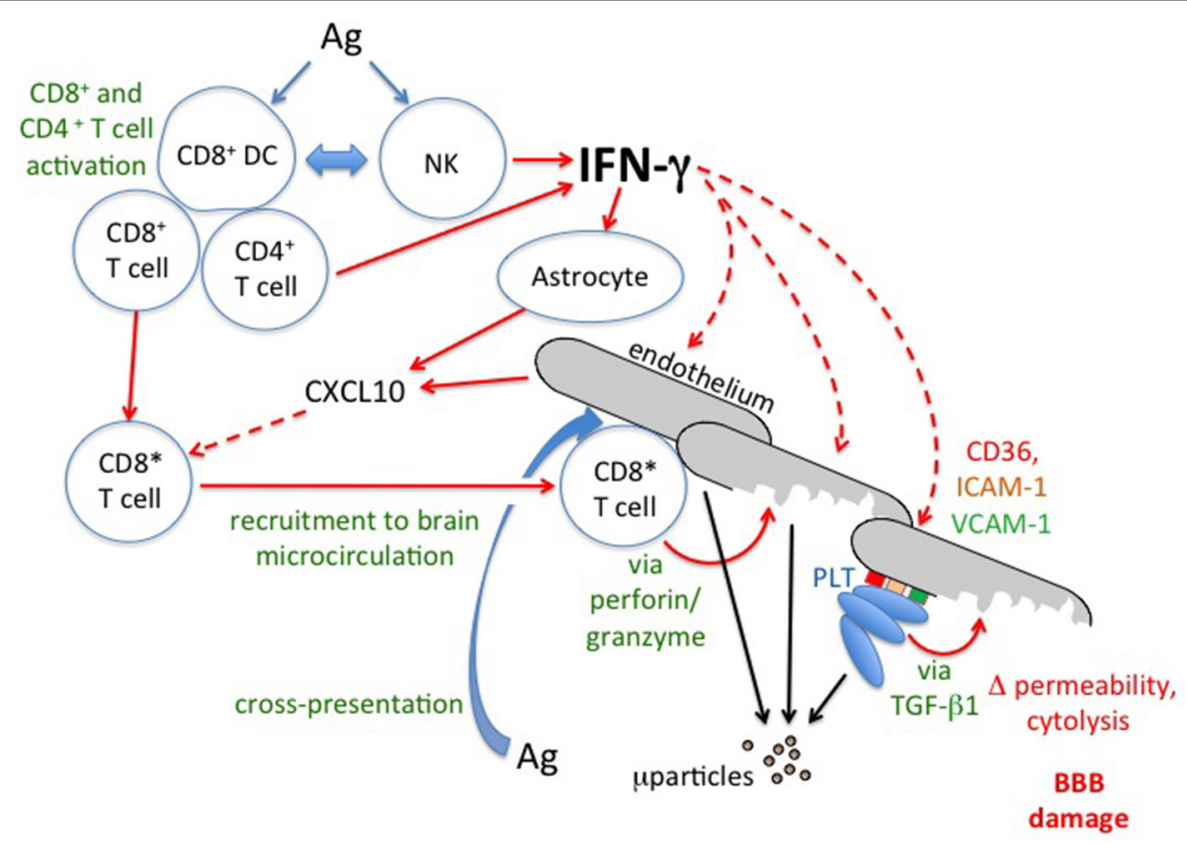

FIGURE 9 | IFN- $\gamma$ and the immunopathology of cerebral malaria. Schematic based on intervention studies in experimental cerebral malaria. For discussion of possible relevance to human cerebral malaria see text. Solid lines indicate direct actions (e.g., release of IFN- $\gamma$ ) or transitions (e.g., activation of $\mathrm{CD}^{+} \mathrm{T}$ cells to $\mathrm{CD} 8^{*}$ ), broken lines indicate influences of secreted factors (IFN- $\gamma$ and $\mathrm{CXCL10}$ ). Ag, malaria antigen; BBB, blood-brain barrier; ICAM-I, intercellular adhesion molecule-1; $\mu$ particles, microparticles; NK, Natural Killer cell; PLT, platelets; TGF- $\beta 1$, transforming growth factor- $\beta 1$; VCAM-1, vascular cell adhesion molecule-1. can enhance platelet binding to endothelial surfaces, presumably via CD36 and/or ICAM-1, and increase the proportion of brain endothelial cells that undergo apoptosis, as measured by FITC-BrdU nuclear fragmentation, when compared to those cocultured with either PRBC or platelets alone. The effect of IFN- $\gamma$ (20.0\% of apoptotic cells) is however weaker than that of lymphotoxin $\alpha$ and TNF (25.5 and 45.2\%, respectively) (Wassmer et al., 2006a). Stimulation of brain endothelial cells by IFN- $\gamma$ also enhances their microparticle release, with different kinetics and response frequencies of cells compared to TNF stimulation (Latham et al., 2013).

Taken together, these data indicate that IFN- $\gamma$ participates in cerebral malaria pathogenesis by affecting endothelial integrity.

A less commonly known product of the endothelium in cerebral malaria is indoleamine dioxygenase-1 (IDO-1), one of three intracellular enzymes that convert tryptophan into $\mathrm{N}$-formylkynurenine. This is the first step in the kynurenine pathway, which leads to the production of numerous biologicallyactive molecules (Ball et al., 2009). IDO-1 expression is regulated by IFN- $\gamma$. As reviewed previously (Hunt et al., 2006; Combes et al., 2012), the kynurenine pathway is activated in human (Medana et al., 2003) and experimental (Sanni et al., 1998) cerebral malaria. IDO-1 expression is induced by IFN- $\gamma$ selectively in endothelial cells in murine malaria infections (Hansen et al., 2004). This probably is a tissue protective response, but one that can become dysregulated in the brain during PbA infection, contributing to abnormalities in neuronal function (Hunt et al., 2006). A striking imbalance in kynurenine pathway metabolites in favor of the neuroexcitotoxin quinolinic acid is observed in the mouse brain as the neuronal symptoms develop (Sanni et al., 1998). However, IDO-1 GKO mice are not protected against fatal cerebral malaria (Miu et al., 2009), although pharmacological inhibition of the production of deleterious metabolites through the kynurenine pathway does reduce mortality (Clark et al., 2005; Miu et al., 2009). These somewhat conflicting findings require explanation.

Activation of the kynurenine pathway in endothelial cells restricts the growth of some bacteria, viruses and parasites (Adam et al., 2005), probably via depletion of tryptophan. However, this is not true of $P f$ (Figure 8). At the systemic level, the IFN$\gamma /$ IDO-1/kynurenine axis appears to be an important mechanism contributing to the hypotension associated with murine malaria (Wang et al., 2010), but this has not been investigated to date in the clinical disease.

\section{SUMMARY AND CONCLUSIONS}

Research during the last 25 years has put considerable flesh on the bones of the concept that IFN- $\gamma$ is a major driving factor in the pathogenesis of cerebral malaria (Figure 9). Immunopathological studies employing interventions, most prominently the use of gene knockout mice, have provided a great deal of molecular information about the multiple levels of IFN- $\gamma$ involvement in experimental cerebral malaria. There is no similarly comprehensive body of evidence derived from studies of the human condition. However, harking back to undergraduate lectures, "absence of evidence is not the same as evidence of absence." Some of the relevant correlative evidence reported in clinical or post-mortem studies has been summarized in this 
article. We contend that further investigation of how the two major proposed mechanisms of cerebral malaria pathogenesis might interact, and the roles of IFN- $\gamma$ therein, would be beneficial. To this end, we also strongly agree with the sentiment expressed at the 2010 Keystone Symposium on Malaria that "experimental and human studies should be more closely linked so that they inform each other, and that there should be wider access to relevant clinical material" (Langhorne et al., 2011).

\section{ACKNOWLEDGMENTS}

Work in the laboratories of Nicholas H. Hunt, Helen J. Ball, Valéry Combes, and Georges E. R. Grau was supported by grants from the National Health and Medical Research Council of Australia and the Australian Research Council.

\section{REFERENCES}

Adam, R., Russing, D., Adams, O., Ailyati, A., Sik Kim, K., Schroten, H., et al. (2005). Role of human brain microvascular endothelial cells during central nervous system infection. Significance of indoleamine 2,3-dioxygenase in antimicrobial defence and immunoregulation. Thromb. Haemost. 94, 341-346. doi: 10.1267/THRO05020341

Adams, S., Brown, H., and Turner, G. (2002). Breaking down the blood-brain barrier: signaling a path to cerebral malaria? Trends Parasitol. 18, 360-366. doi: 10.1016/S1471-4922(02)02353-X

Amani, V., Vigario, A. M., Belnoue, E., Marussig, M., Fonseca, L., Mazier, D., et al. (2000). Involvement of IFN-gamma receptor-mediated signaling in pathology and anti-malarial immunity induced by Plasmodium berghei infection. Eur. J. Immunol. 30, 1646-1655. doi: 10.1002/1521-4141(200006)30:6<1646::AIDIMMU1646>3.0.CO;2-0

Amante, F. H., Haque, A., Stanley, A. C., Rivera, F. D., Randall, L. M., Wilson, Y. A., et al. (2010). Immune-mediated mechanisms of parasite tissue sequestration during experimental cerebral malaria. J. Immunol. 185, 3632-3642. doi: 10.4049/jimmunol.1000944

Amante, F. H., Stanley, A. C., Randall, L. M., Zhou, Y., Haque, A., McSweeney, K., et al. (2007). A role for natural regulatory $\mathrm{T}$ cells in the pathogenesis of experimental cerebral malaria. Am. J. Pathol. 171, 548-559. doi: 10.2353/ajpath.2007.061033

Ampawong, S., Chaisri, U., Viriyavejakul, P., Nontprasert, A., Grau, G. E., and Pongponratn, E. (2014). Electron microscopic features of brain edema in rodent cerebral malaria in relation to glial fibrillary acidic protein expression. Int. J. Clin. Exp. Pathol. 7, 2056-2067.

Armah, H. B., Wilson, N. O., Sarfo, B. Y., Powell, M. D., Bond, V. C., Anderson, W., et al. (2007). Cerebrospinal fluid and serum biomarkers of cerebral malaria mortality in Ghanaian children. Malar. J. 6:147. doi: 10.1186/1475-2875-6-147

Armah, H., Dodoo, A. K., Wiredu, E. K., Stiles, J. K., Adjei, A. A., Gyasi, R. K., et al. (2005). High-level cerebellar expression of cytokines and adhesion molecules in fatal, paediatric, cerebral malaria. Ann. Trop. Med. Parasitol. 99, 629-647. doi: $10.1179 / 136485905$ X51508

Artavanis-Tsakonas, K., and Riley, E. M. (2002). Innate immune response to malaria: rapid induction of IFN-gamma from human NK cells by live Plasmodium falciparum-infected erythrocytes. J. Immunol. 169, 2956-2963. doi: 10.4049/jimmunol.169.6.2956

Ball, E. A., Sambo, M. R., Martins, M., Trovoada, M. J., Benchimol, C., Costa, J., et al. (2013). IFNAR1 controls progression to cerebral malaria in children and CD8+T cell brain pathology in Plasmodium berghei-infected mice. J. Immunol. 190, 5118-5127. doi: 10.4049/jimmunol.1300114

Ball, H. J., Yuasa, H. J., Austin, C. J., Weiser, S., and Hunt, N. H. (2009). Indoleamine 2,3-dioxygenase-2; a new enzyme in the kynurenine pathway. Int. J. Biochem. Cell Biol. 41, 467-471. doi: 10.1016/j.biocel.2008.01.005

Baratin, M., Roetynck, S., Lepolard, C., Falk, C., Sawadogo, S., Uematsu, S., et al. (2005). Natural killer cell and macrophage cooperation in MyD88-dependent innate responses to Plasmodium falciparum. Proc. Natl. Acad. Sci. U.S.A. 102, 14747-14752. doi: 10.1073/pnas.0507355102

Bauer, P. R., Van Der Heyde, H. C., Sun, G., Specian, R. D., and Granger, D. N. (2002). Regulation of endothelial cell adhesion molecule expression in an experimental model of cerebral malaria. Microcirculation 9, 463-470. doi: 10.1038/sj.mn.7800159

Beare, N. A., Southern, C., Chalira, C., Taylor, T. E., Molyneux, M. E., and Harding, S. P. (2004). Prognostic significance and course of retinopathy in children with severe malaria. Arch. Ophthalmol. 122, 1141-1147. doi: 10.1001/archopht.122.8.1141

Belnoue, E., Kayibanda, M., Vigario, A. M., Deschemin, J. C., van Rooijen, N., Viguier, M., et al. (2002). On the pathogenic role of brain-sequestered alphabeta CD8+T cells in experimental cerebral malaria. J. Immunol. 169, 6369-6375. doi: 10.4049/jimmunol.169.11.6369

Belnoue, E., Potter, S. M., Rosa, D. S., Mauduit, M., Gruner, A. C., Kayibanda, M., et al. (2008). Control of pathogenic CD8+T cell migration to the brain by IFNgamma during experimental cerebral malaria. Parasite Immunol. 30, 544-553. doi: 10.1111/j.1365-3024.2008.01053.x

Berendt, A. R., Turner, G. D. H., and Newbold, C. I. (1994). Cerebral malaria: the sequestration hypothesis. Parasitol. Today 10, 412-414. doi: 10.1016/01694758(94)90238-0

Billiau, A., and Matthys, P. (2009). Interferon-gamma: a historical perspective. Cytokine Growth Factor Rev. 20, 97-113. doi: 10.1016/j.cytogfr.2009.02.004

Birbeck, G. L., Beare, N., Lewallen, S., Glover, S. J., Molyneux, M. E., Kaplan, P. W., et al. (2010). Identification of malaria retinopathy improves the specificity of the clinical diagnosis of cerebral malaria: findings from a prospective cohort study. Am. J. Trop. Med. Hyg. 82, 231-234. doi: 10.4269/ajtmh.2010.09-0532

Brown, H., Hien, T. T., Day, N., Mai, N., Chuong, L. V., Chau, T. T., et al. (1999a). Evidence of blood-brain barrier dysfunction in human cerebral malaria. Neuropathol. Appl. Neurobiol. 25, 331-340. doi: 10.1046/j.13652990.1999.00188.x

Brown, H., Rogerson, S., Taylor, T., Tembo, M., Mwenechanya, J., Molyneux, M., et al. (2001). Blood-brain barrier function in cerebral malaria in Malawian children. Am. J. Trop. Med. Hyg. 64, 207-213.

Brown, H., Turner, G., Rogerson, S., Tembo, M., Mwenechanya, J., Molyneux, M., et al. (1999b). Cytokine expression in the brain in human cerebral malaria. J. Infect. Dis. 180, 1742-1746. doi: 10.1086/315078

Campanella, G. S., Tager, A. M., El Khoury, J. K., Thomas, S. Y., Abrazinski, T. A., Manice, L. A., et al. (2008). Chemokine receptor CXCR3 and its ligands CXCL9 and CXCL10 are required for the development of murine cerebral malaria. Proc. Natl. Acad. Sci. U.S.A. 105, 4814-4819. doi: 10.1073/pnas.08015 44105

Chan-Ling, T., Neill, A. L., and Hunt, N. H. (1992). Early microvascular changes in murine cerebral detected using retinal wholemounts. Am. J. Pathol. 140, 1121-1130.

Clark, C. J., Mackay, G. M., Smythe, G. A., Bustamante, S., Stone, T. W., and Phillips, R. S. (2005). Prolonged survival of a murine model of cerebral malaria by kynurenine pathway inhibition. Infect. Immun. 73, 5249-5251. doi: 10.1128/IAI.73.8.5249-5251.2005

Clark, I. A., and Rockett, K. A. (1994). The cytokine theory of human cerebral malaria. Parasitol. Today 10, 410-412. doi: 10.1016/0169-4758(94) 90237-2

Claser, C., Malleret, B., Gun, S. Y., Wong, A. Y., Chang, Z. W., Teo, P., et al. (2011). CD8+T cells and IFN-gamma mediate the time-dependent accumulation of infected red blood cells in deep organs during experimental cerebral malaria. PLOS ONE 6:e18720. doi: 10.1371/journal.pone. 0018720

Combes, V., Coltel, N., Faille, D., Wassmer, S. C., and Grau, G. E. (2006). Cerebral malaria: role of microparticles and platelets in alterations of the blood-brain barrier. Int. J. Parasitol. 36, 541-546. doi: 10.1016/j.ijpara.2006.02.005

Combes, V., El-Assaad, F., Faille, D., Jambou, R., Hunt, N. H., and Grau, G. E. (2010). Microvesiculation and cell interactions at the brain-endothelial interface in cerebral malaria pathogenesis. Prog. Neurobiol. 91, 140-151. doi: 10.1016/j.pneurobio.2010.01.007

Combes, V., Guillemin, G. J., Chan-Ling, T., Hunt, N. H., and Grau, G. E. R. (2012). The crossroads of neuroinflammation in infectious diseases: endothelial cells and astrocytes. Trends Parasitol. 28, 311-319. doi: 10.1016/j.pt.2012. 05.008

Cunnington, A. J., Riley, E. M., and Walther, M. (2013). Stuck in a rut? Reconsidering the role of parasite sequestration in severe malaria syndromes. Trends Parasitol. 29, 585-592. doi: 10.1016/j.pt.2013.10.004

Das, B. S., Mohanty, S., Mishra, S. K., Patnaik, J. K., Satpathy, S. K., Mohanty, D., et al. (1991). Increased cerebrospinal fluid protein and lipid peroxidation 
products in patients with cerebral malaria. Trans. R. Soc. Trop. Med. Hyg. 85, 733-734. doi: 10.1016/0035-9203(91)90436-3

de Kossodo, S., and Grau, G. E. (1993). Role of cytokines and adhesion molecules in malaria immunopathology. Stem Cells 11, 41-48. doi: 10.1002/stem.55301 10108

de Kossodo, S., Monso, C., Juillard, P., Velu, T., Goldman, M., and Grau, G. E. (1997). Interleukin-10 modulates susceptibility in experimental cerebral malaria. Immunology 91, 536-540. doi: 10.1046/j.1365-2567.1997.00290.x

deWalick, S., Amante, F. H., McSweeney, K. A., Randall, L. M., Stanley, A. C., Haque, A., et al. (2007). Cutting edge: conventional dendritic cells are the critical APC required for the induction of experimental cerebral malaria. J. Immunol. 178, 6033-6037. doi: 10.4049/jimmunol.178.10.6033

D’Ombrain, M. C., Hansen, D. S., Simpson, K. M., and Schofield, L. (2007). gammadelta-T cells expressing NK receptors predominate over NK cells and conventional $\mathrm{T}$ cells in the innate IFN-gamma response to Plasmodium falciparum malaria. Eur. J. Immunol. 37, 1864-1873. doi: 10.1002/eji.200636889

El-Assaad, F., Wheway, J., Mitchell, A. J., Lou, J., Hunt, N. H., Combes, V., et al. (2013). Cytoadherence of Plasmodium berghei-infected red blood cells to murine brain and lung microvascular endothelial cells in vitro. Infect. Immun. 81, 3984-3991. doi: 10.1128/IAI.00428-13

Engwerda, C. R., Mynott, T. L., Sawhney, S., De Souza, J. B., Bickle, Q. D., and Kaye, P. M. (2002). Locally up-regulated lymphotoxin alpha, not systemic tumor necrosis factor alpha, is the principle mediator of murine cerebral malaria. J. Exp. Med. 195, 1371-1377. doi: 10.1084/jem.20020128

Favre, N., Da Laperousaz, C., Ryffel, B., Weiss, N. A., Imhof, B. A., Rudin, W., et al. (1999). Role of ICAM-1 (CD54) in the development of murine cerebral malaria. Microbes Infect. 1, 961-968. doi: 10.1016/S1286-4579(99)80513-9

Good, M. F., Xu, H., Wykes, M., and Engwerda, C. R. (2005). Development and regulation of cell-mediated immune responses to the blood stages of malaria: implications for vaccine research. Annu. Rev. Immunol. 23, 69-99. doi: 10.1146/annurev.immunol.23.021704.115638

Grau, G. E., and De Kossodo, S. (1994). Cerebral malaria: mediators, mechanical obstruction or more? Parasitol. Today 10, 408-410. doi: 10.1016/01694758(94)90236-4

Grau, G. E., de Moerloose, P., Bulla, O., Lou, J., Lei, Z., Reber, G., et al. (1997). Haemostatic properties of human pulmonary and cerebral microvascular endothelial cells. Thromb. Haemost. 77, 585-590.

Grau, G. E., Heremans, H., Piguet, P. F., Pointaire, P., Lambert, P. H., Billiau, A., et al. (1989). Monoclonal antibody against interferon gamma can prevent experimental cerebral malaria and its associated overproduction of tumour necrosis factor. Proc. Natl. Acad. Sci. U.S.A. 86, 5572-5574. doi: 10.1073/pnas. 86.14.5572

Grau, G. E., Mackenzie, C. D., Carr, R. A., Redard, M., Pizzolato, G., Allasia, C., et al. (2003). Platelet accumulation in brain microvessels in fatal pediatric cerebral malaria. J. Infect. Dis. 187, 461-466. doi: 10.1086/367960

Grau, G. E., Piguet, P. F., Engers, H. D., Louis, J. A., Vassalli, P., and Lambert, P. H. (1986). L3T4+ lymphocytes play a major role in the pathogenesis of murine cerebral malaria. J. Immunol. 137, 2348-2354.

Hansen, A. M., Ball, H. J., Mitchell, A. J., Miu, J., Takikawa, O., and Hunt, N. H. (2004). Increased expression of indoleamine 2,3-dioxygenase in murine malaria infection is predominantly localised to the vascular endothelium. Int. J. Parasitol. 34, 1309-1319. doi: 10.1016/j.ijpara.2004.07.008

Hansen, D. S., Bernard, N. J., Nie, C. Q., and Schofield, L. (2007). NK cells stimulate recruitment of CXCR3+T cells to the brain during Plasmodium bergheimediated cerebral malaria. J. Immunol. 178, 5779-5788. doi: 10.4049/jimmunol.178.9.5779

Hansen, D. S., Evans, K. J., D’Ombrain, M. C., Bernard, N. J., Sexton, A. C., Buckingham, L., et al. (2005). The natural killer complex regulates severe malarial pathogenesis and influences acquired immune responses to Plasmodium berghei ANKA. Infect. Immun. 73, 2288-2297. doi: 10.1128/IAI.73.4.22882297.2005

Hansen, D. S., Ryg-Cornejo, V., Ioannidis, L. J., Chiu, C. Y., Ly, A., Nie, C. Q., et al. (2014). The contribution of natural killer complex loci to the development of experimental cerebral malaria. PLOS ONE 9:e93268. doi: 10.1371/journal.pone.0093268

Hansen, D. S., Siomos, M. A., Buckingham, L., Scalzo, A. A., and Schofield, L. (2003). Regulation of murine cerebral malaria pathogenesis by CD1drestricted NKT cells and the natural killer complex. Immunity 18, 391-402. doi: 10.1016/S1074-7613(03)00052-9
Haque, A., Best, S. E., Unosson, K., Amante, F. H., de Labastida, F., Anstey, N. M., et al. (2011). Granzyme B expression by CD8+T cells is required for the development of experimental cerebral malaria. J. Immunol. 186, 6148-6156. doi: 10.4049/jimmunol.1003955

Hempel, C., Combes, V., Hunt, N. H., Kurtzhals, J. A., and Grau, G. E. (2011). CNS hypoxia is more pronounced in murine cerebral than noncerebral malaria and is reversed by erythropoietin. Am. J. Pathol. 179, 1939-1950. doi: 10.1016/j.ajpath.2011.06.027

Hensmann, M., and Kwiatkowski, D. (2001). Cellular basis of early cytokine response to Plasmodium falciparum. Infect. Immun. 69, 2364-2371. doi: 10.1128/IAI.69.4.2364-2371.2001

Ho, M., Schollaardt, T., Niu, X., Looareesuwan, S., Patel, K. D., and Kubes, P. (1998b). Characterization of Plasmodium falciparum-infected erythrocyte and P-selectin interaction under flow conditions. Blood 91, 4803-4809.

Ho, M., Schollaardt, T., Snape, S., Looareesuwan, S., Suntharasamai, P., and White, N. J. (1998a). Endogenous interleukin-10 modulates proinflammatory response in Plasmodium falciparum malaria. J. Infect. Dis. 178, 520-525. doi: $10.1086 / 515640$

Horowitz, A., Newman, K. C., Evans, J. H., Korbel, D. S., Davis, D. M., and Riley, E. M. (2010). Cross-talk between T cells and NK cells generates rapid effector responses to Plasmodium falciparum-infected erythrocytes. J. Immunol. 184, 6043-6052. doi: 10.4049/jimmunol.1000106

Howland, S. W., Poh, C. M., Gun, S. Y., Claser, C., Malleret, B., Shastri, N., et al. (2013). Brain microvessel cross-presentation is a hallmark of experimental cerebral malaria. EMBO Mol. Med. 5, 984-999. doi: 10.1002/emmm.2012 02273

Hunt, N. H., Golenser, J., Chan-Ling, T., Parekh, S., Rae, C., Potter, S., et al. (2006) Immunopathogenesis of cerebral malaria. Int. J. Parasitol. 36, 569-582. doi: 10.1016/j.ijpara.2006.02.016

Hunt, N. H., and Grau, G. E. (2003). Cytokines: accelerators and brakes in the pathogenesis of cerebral malaria. Trends Immunol. 24, 491-499. doi: 10.1016/S1471-4906(03)00229-1

Jelic, S., and Le Jemtel, T. H. (2008). Inflammation, oxidative stress, and the vascular endothelium in obstructive sleep apnea. Trends Cardiovasc. Med. 18, 253-260. doi: 10.1016/j.tcm.2008.11.008

John, C. C., Bangirana, P., Byarugaba, J., Opoka, R. O., Idro, R., Jurek, A. M., et al. (2008). Cerebral malaria in children is associated with long-term cognitive impairment. Pediatrics 122, e92-e99. doi: 10.1542/peds.2007-3709

John, G. R., Lee, S. C., and Brosnan, C. F. (2003). Cytokines: powerful regulators of glial cell activation. Neuroscientist 9, 10-22. doi: 10.1177/1073858402239587

Khaw, L. T., Ball, H. J., Golenser, J., Combes, V., Grau, G. E., Wheway, J., et al. (2013). Endothelial cells potentiate interferon-gamma production in a novel tripartite culture model of human cerebral malaria. PLOS ONE 8:e69521. doi: 10.1371/journal.pone.0069521

Kihara, M., Carter, J. A., and Newton, C. R. (2006). The effect of Plasmodium falciparum on cognition: a systematic review. Trop. Med. Int. Health 11, 386-397. doi: 10.1111/j.1365-3156.2006.01579.x

Korbel, D. S., Newman, K. C., Almeida, C. R., Davis, D. M., and Riley, E. M. (2005). Heterogeneous human NK cell responses to Plasmodium falciparuminfected erythrocytes. J. Immunol. 175, 7466-7473. doi: 10.4049/jimmunol.175. 11.7466

Kwiatkowski, D. P. (2005). How malaria has affected the human genome and what human genetics can teach us about malaria. Am. J. Hum. Genet. 77, 171-192. doi: $10.1086 / 432519$

Langhorne, J., Buffet, P., Galinski, M., Good, M., Harty, J., Leroy, D., et al. (2011). The relevance of non-human primate and rodent malaria models for humans. Malar. J. 10:23. doi: 10.1186/1475-2875-10-23

Latham, S. L., Chaponnier, C., Dugina, V., Couraud, P. O., Grau, G. E., and Combes, V. (2013). Cooperation between beta- and gamma-cytoplasmic actins in the mechanical regulation of endothelial microparticle formation. FASEB J. 27, 672-683. doi: 10.1096/fj.12-216531

Lau, L. S., Fernandez Ruiz, D., Davey, G. M., de Koning-Ward, T. F., Papenfuss, A. T., Carbone, F. R., et al. (2011). Blood-stage Plasmodium berghei infection generates a potent, specific CD8+T-cell response despite residence largely in cells lacking MHC I processing machinery. J. Infect. Dis. 204, 1989-1996. doi: 10.1093/infdis/jir656

Liberto, C. M., Albrecht, P. J., Herx, L. M., Yong, V. W., and Levison, S. W. (2004) Pro-regenerative properties of cytokine-activated astrocytes. J. Neurochem. 89, 1092-1100. doi: 10.1111/j.1471-4159.2004.02420.x 
Lou, J., Donati, Y. R., Juillard, P., Giroud, C., Vesin, C., Mili, N., et al. (1997). Platelets play an important role in TNF-induced microvascular endothelial cell pathology. Am. J. Pathol. 151, 1397-1405.

Lovegrove, F. E., Gharib, S. A., Patel, S. N., Hawkes, C. A., Kain, K. C., and Liles, W. C. (2007). Expression microarray analysis implicates apoptosis and interferonresponsive mechanisms in susceptibility to experimental cerebral malaria. Am. J. Pathol. 171, 1894-1903. doi: 10.2353/ajpath.2007.070630

Lundie, R. J., de Koning-Ward, T. F., Davey, G. M., Nie, C. Q., Hansen, D. S., Lau, L. S., et al. (2008). Blood-stage Plasmodium infection induces CD8+T lymphocytes to parasite-expressed antigens, largely regulated by CD8alpha+ dendritic cells. Proc. Natl. Acad. Sci. U.S.A. 105, 14509-14514. doi: 10.1073/pnas.0806727105

Mackintosh, C. L., Beeson, J. G., and Marsh, K. (2004). Clinical features and pathogenesis of severe malaria. Trends Parasitol. 20, 597-603. doi: 10.1016/j.pt.2004.09.006

McCall, M. B., and Sauerwein, R. W. (2010). Interferon-gamma-central mediator of protective immune responses against the pre-erythrocytic and blood stage of malaria. J. Leukoc. Biol. 88, 1131-1143. doi: 10.1189/jlb.0310137

McQuillan, J. A., Mitchell, A. J., Ho, Y. F., Combes, V., Ball, H. J., Golenser, J., et al. (2011). Coincident parasite and CD8 T cell sequestration is required for development of experimental cerebral malaria. Int. J. Parasitol. 41, 155-163. doi: 10.1016/j.ijpara.2010.08.003

Medana, I. M., Chan-Ling, T., and Hunt, N. H. (1996). Redistribution and degeneration of retinal astrocytes in experimental murine cerebral malaria: relationship to disruption of the blood-retinal barrier. Glia 16, 51-64.

Medana, I. M., Day, N. P., Hien, T. T., Mai, N. T., Bethell, D., Phu, N. H., et al. (2002). Axonal injury in cerebral malaria. Am. J. Pathol. 160, 655-666. doi: 10.1016/S0002-9440(10)64885-7

Medana, I. M., Day, N. P., Salahifar-Sabet, H., Stocker, R., Smythe, G., Bwanaisa, L., et al. (2003). Metabolites of the kynurenine pathway of tryptophan metabolism in the cerebrospinal fluid of Malawian children with malaria. J. Infect. Dis. 188, 844-849. doi: 10.1086/377583

Medana, I. M., Idro, R., and Newton, C. R. (2007). Axonal and astrocyte injury markers in the cerebrospinal fluid of Kenyan children with severe malaria. J. Neurol. Sci. 258, 93-98. doi: 10.1016/j.jns.2007.03.005

Miller, C. H., Maher, S. G., and Young, H. A. (2009). Clinical use of interferon-gamma. Ann. N.Y. Acad. Sci. 1182, 69-79. doi: 10.1111/j.17496632.2009.05069.x

Mitchell, A. J., Yau, B., McQuillan, J. A., Ball, H. J., Too, L. K., Abtin, A., et al. (2012). Inflammasome-dependent IFN-gamma drives pathogenesis in streptococcus pneumoniae meningitis. J. Immunol. 189, 4970-4980. doi: 10.4049/jimmunol.1201687

Miu, J., Ball, H. J., Mellor, A. L., and Hunt, N. H. (2009). Effect of indoleamine dioxygenase-1 deficiency and kynurenine pathway inhibition on murine cerebral malaria. Int. J. Parasitol. 39, 363-370. doi: 10.1016/j.ijpara.2008.10.005

Miu, J., Hunt, N. H., and Ball, H. J. (2008b). Predominance of interferon-related responses in the brain during murine malaria, as identified by microarray analysis. Infect. Immun. 76, 1812-1824. doi: 10.1128/IAI.01650-07

Miu, J., Mitchell, A. J., Muller, M., Carter, S. L., Manders, P. M., McQuillan, J. A., et al. (2008a). Chemokine gene expression during fatal murine cerebral malaria and protection due to CXCR3 deficiency. J. Immunol. 180, 1217-1230. doi: 10.4049/jimmunol.180.2.1217

Molyneux, M. E., Taylor, T. E., Wirima, J. J., and Borgstein, A. (1989). Clinical features and prognostic indicators in paediatric cerebral malaria: a study of 131 comatose Malawian children. Q. J. Med. 71, 441-459.

Morrell, C. N., Srivastava, K., Swaim, A., Lee, M. T., Chen, J., Nagineni, C., et al. (2011). Beta interferon suppresses the development of experimental cerebral malaria. Infect. Immun. 79, 1750-1758. doi: 10.1128/IAI.00810-10

Nedergaard, M., and Dirnagl, U. (2005). Role of glial cells in cerebral ischemia. Glia 50, 281-286. doi: 10.1002/glia.20205

Newman, K. C., Korbel, D. S., Hafalla, J. C., and Riley, E. M. (2006). Cross-talk with myeloid accessory cells regulates human natural killer cell interferon-gamma responses to malaria. PLoS Pathog. 2:e118. doi: 10.1371/journal.ppat.0020118

Newton, C. R., Hien, T. T., and White, N. (2000). Cerebral malaria. J. Neurol. Neurosurg. Psychiatr. 69, 433-441. doi: 10.1136/jnnp.69.4.433

Nie, C. Q., Bernard, N. J., Norman, M. U., Amante, F. H., Lundie, R. J., Crabb, B. S., et al. (2009). IP-10-mediated T cell homing promotes cerebral inflammation over splenic immunity to malaria infection. PLoS Pathog. 5:e1000369. doi: 10.1371/journal.ppat.1000369
Nie, C. Q., Bernard, N. J., Schofield, L., and Hansen, D. S. (2007). CD4+ CD25+ regulatory $\mathrm{T}$ cells suppress $\mathrm{CD} 4+\mathrm{T}$ cell function and inhibit the development of Plasmodium berghei-specific $\mathrm{TH} 1$ responses involved in cerebral malaria pathogenesis. Infect. Immun. 75, 2275-2282. doi: 10.1128/IAI.01783-06

Nitcheu, J., Bonduelle, O., Combadiere, C., Tefit, M., Seilhean, D., Mazier, D., et al. (2003). Perforin-dependent brain-infiltrating cytotoxic CD8 $(+)$ T lymphocytes mediate experimental cerebral malaria pathogenesis. J. Immunol. 170, 2221-2228. doi: 10.4049/jimmunol.170.4.2221

Omer, F. M., and Riley, E. M. (1998). Transforming growth factor beta production is inversely correlated with severity of murine malaria infection. J. Exp. Med. 188, 39-48. doi: 10.1084/jem.188.1.39

Palomo, J., Fauconnier, M., Coquard, L., Gilles, M., Meme, S., Szeremeta, F., et al. (2013). Type I interferons contribute to experimental cerebral malaria development in response to sporozoite or blood-stage Plasmodium berghei ANKA. (2013). Eur. J. Immunol. 43, 2683-2695. doi: 10.1002/eji.201343327

Panickar, K. S., and Norenberg, M. D. (2005). Astrocytes in cerebral ischemic injury: Morphological and general considerations. Glia 50, 287-298. doi: 10.1002/glia.20181

Parekh, S. B., Bubb, W. A., Hunt, N. H., and Rae, C. (2006). Brain metabolic markers reflect susceptibility status in cytokine gene knockout mice with murine cerebral malaria. Int. J. Parasitol. 36, 1409-1418. doi: 10.1016/j.ijpara.2006.07.004

Patnaik, J. K., Das, B. S., Mishra, S. K., Mohanty, S., Satpathy, S. K., and Mohanty, D. (1994). Vascular clogging, mononuclear cell margination, and enhanced pathogenesis of human cerebral malaria. Am. J. Trop. Med. Hyg. 51, 642-647.

Penet, M. F., Viola, A., Confort-Gouny, S., Le Fur, Y., Duhamel, G., Kober, F., et al. (2005). Imaging experimental cerebral malaria in vivo: significant role of ischemic brain edema. J. Neurosci. 25, 7352-7358. doi: 10.1523/JNEUROSCI.1002-05.2005

Petzelbauer, P., Bender, J. R., Wilson, J., and Pober, J. S. (1993). Heterogeneity of dermal microvascular endothelial cell antigen expression and cytokine responsiveness in situ and in cell culture. J. Immunol. 151, 5062-5072.

Piva, L., Tetlak, P., Claser, C., Karjalainen, K., Renia, L., and Ruedl, C. (2012). Cutting edge: Clec9A + dendritic cells mediate the development of experimental cerebral malaria. J. Immunol. 189, 1128-1132. doi: 10.4049/jimmunol. 1201171

Ponsford, M. J., Medana, I. M., Prapansilp, P., Hien, T. T., Lee, S. J., Dondorp, A. M., et al. (2012). Sequestration and microvascular congestion are associated with coma in human cerebral malaria. J. Infect. Dis. 205, 663-671. doi: 10.1093/infdis/jir812

Potter, S., Chaudhri, G., Hansen, A., and Hunt, N. H. (1999). Fas and perforin contribute to the pathogenesis of murine cerebral malaria. Redox Rep. 4, 333-335. doi: 10.1179/135100099101535070

Potter, S. M., Chan-Ling, T., Ball, H. J., Mitchell, A., Miu, J., Maluish, L., et al. (2006). Perforin-mediated apoptosis of cerebral microvascular endothelial cells during experimental cerebral malaria. Int. J. Parasitol. 36, 485-496. doi: 10.1016/j.ijpara.2005.12.005

Rae, C., McQuillan, J. A., Parekh, S. B., Bubb, W. A., Weiser, S., Balcar, V. J., et al. (2004). Brain gene expression, metabolism, and bioenergetics: interrelationships in murine models of cerebral and noncerebral malaria. FASEB J. 18, 499-510. doi: 10.1096/fj.03-0543com

Riley, E. M., Wahl, S., Perkins, D. J., and Schofield, L. (2006). Regulating immunity to malaria. Parasite Immunol. 28, 35-49. doi: 10.1111/j.1365-3024.2006.00775.x

Rossi, D. J., Brady, J. D., and Mohr, C. (2007). Astrocyte metabolism and signaling during brain ischemia. Nat. Neurosci. 10, 1377-1386. doi: 10.1038/nn2004

Rossi, D., and Volterra, A. (2009). Astrocytic dysfunction: Insights on the role in neurodegeneration. Brain Res. Bull. 80, 224-232. doi: 10.1016/j.brainresbull.2009.07.012

Ryg-Cornejo, V., Nie, C. Q., Bernard, N. J., Lundie, R. J., Evans, K. J., Crabb, B. S., et al. (2013). NK cells and conventional dendritic cells engage in reciprocal activation for the induction of inflammatory responses during Plasmodium berghei ANKA infection. Immunobiology 218, 263-271. doi: 10.1016/j.imbio.2012.05.018

Saha, B., Jyothi Prasanna, S., Chandrasekar, B., and Nandi, D. (2010). Gene modulation and immunoregulatory roles of interferon gamma. Cytokine 50, 1-14. doi: 10.1016/j.cyto.2009.11.021

Sanni, L. A., Rae, C., Maitland, A., Stocker, R., and Hunt, N. H. (2001). Is ischemia involved in the pathogenesis of murine cerebral malaria? Am. J. Pathol. 159, 1105-1112. doi: 10.1016/S0002-9440(10)61786-5 
Sanni, L. A., Thomas, S. R., Tattam, B. N., Moore, D. E., Chaudhri, G., Stocker, R., et al. (1998). Dramatic changes in oxidative tryptophan metabolism along the kynurenine pathway in experimental cerebral and noncerebral malaria. Am. J. Pathol. 152, 611-619.

Schofield, L., and Grau, G. E. (2005). Immunological processes in malaria pathogenesis. Nat. Rev. Immunol. 5, 722-735. doi: 10.1038/nri1686

Schroder, K., Hertzog, P. J., Ravasi, T., and Hume, D. A. (2004). Interferon-gamma: an overview of signals, mechanisms and functions. J. Leukoc. Biol. 75, 163-189. doi: $10.1189 /$ jlb.0603252

Takano, T., Oberheim, N., Cotrina, M. L., and Nedergaard, M. (2009). Astrocytes and ischemic injury. Stroke 40(3 Suppl), S8-S12. doi: 10.1161/STROKEAHA.108.533166

Taylor, T. E., Fu, W. J., Carr, R. A., Whitten, R. O., Mueller, J. S., Fosiko, N. G., et al. (2004). Differentiating the pathologies of cerebral malaria by postmortem parasite counts. Nat. Med. 10, 143-145. doi: 10.1038/nm986

Thumwood, C. M., Hunt, N. H., Clark, I. A., and Cowden, W. B. (1988). Breakdown of the blood-brain barrier in murine cerebral malaria. Parasitology 96, 579-589. doi: 10.1017/S0031182000080203

Toro, G., and Roman, G. (1978). Cerebral malaria: disseminated vasculomyelinopathy. Arch Neurol 35, 271-275. doi: 10.1001/archneur.1978.00500290017004

Trendelenburg, G., and Dirnagl, U. (2005). Neuroprotective role of astrocytes in cerebral ischemia: focus on ischemic preconditioning. Glia 50, 307-320. doi: 10.1002/glia.20204

Turner, G. D., Morrison, H., Jones, M., Davis, T. M., Looareesuwan, S., Buley, I. D., et al. (1994). An immunohistochemical study of the pathology of fatal malaria. Evidence for widespread endothelial activation and a potential role for intercellular adhesion molecule-1 in cerebral sequestration. Am. J. Pathol. 145, 1057-1069.

Turner, L., Lavstsen, T., Berger, S. S., Wang, C. W., Petersen, J. E., Avril, M., et al. (2013). Severe malaria is associated with parasite binding to endothelial protein C receptor. Nature 498, 502-505. doi: 10.1038/nature12216

Udomsangpetch, R., Chivapat, S., Viriyavejakul, P., Riganti, M., Wilairatana, P., Pongponratin, E., et al. (1997). Involvement of cytokines in the histopathology of cerebral malaria. Am. J. Trop. Med. Hyg. 57, 501-506.

Van den Steen, P. E., Deroost, K., Van Aelst, I., Geurts, N., Martens, E., Struyf, S., et al. (2008). CXCR3 determines strain susceptibility to murine cerebral malaria by mediating $\mathrm{T}$ lymphocyte migration toward IFN-gammainduced chemokines. Eur. J. Immunol. 38, 1082-1095. doi: 10.1002/eji.200 737906

van der Heyde, H. C., Bauer, P., Sun, G., Chang, W. L., Yin, L., Fuseler, J., et al. (2001). Assessing vascular permeability during experimental cerebral malaria by a radiolabeled monoclonal antibody technique. Infect. Immun. 69, 3460-3465. doi: 10.1128/IAI.69.5.3460-3465.2001

Verkhrasky, A., Krishtal, O. A., and Burnstock, G. (2009). Purinoceptors on neuroglia. Mol. Neurobiol. 39, 190-208. doi: 10.1007/s12035-009-8063-2

Verra, F., Mangano, V. D., and Modiano, D. (2009). Genetics of susceptibility to Plasmodium falciparum: from classical malaria resistance genes towards genome-wide association studies. Parasite Immunol. 31, 234-253. doi: 10.1111/j.1365-3024.2009.01106.x

Vigario, A. M., Belnoue, E., Gruner, A. C., Mauduit, M., Kayibanda, M., Deschemin, J. C., et al. (2007). Recombinant human IFN-alpha inhibits cerebral malaria and reduces parasite burden in mice. J. Immunol. 178, 6416-6425. doi: 10.4049/jimmunol.178.10.6416

Villegas-Mendez, A., Greig, R., Shaw, T. N., de Souza, J. B., Gwyer Findlay, E., Stumhofer, J. S., et al. (2012). IFN-gamma-producing CD4+T cells promote experimental cerebral malaria by modulating CD8 $+\mathrm{T}$ cell accumulation within the brain. J. Immunol. 189, 968-979. doi: 10.4049/jimmunol.1200688

Wahl, S. M., Feldman, G. M., and McCarthy, J. B. (1996). Regulation of leukocyte adhesion and signaling in inflammation and disease. J. Leukoc. Biol. 59, 789-796.

Walther, M., Woodruff, J., Edele, F., Jeffries, D., Tongren, J. E., King, E., et al. (2006). Innate immune responses to human malaria: heterogeneous cytokine responses to blood-stage Plasmodium falciparum correlate with parasitological and clinical outcomes. J. Immunol. 177, 5736-5745. doi: 10.4049/jimmunol.177.8.5736
Wang, Y., Liu, H., McKenzie, G., Witting, P. K., Stasch, J. P., Hahn, M., et al. (2010). Kynurenine is an endothelium-derived relaxing factor produced during inflammation. Nat. Med. 16, 279-285. doi: 10.1038/ nm.2092

Warrell, D. A., Veal, N., Chanthavanich, P., Karbwang, J., White, N. J., Looareesuwan, S., et al. (1988). Cerebral anaerobic glycolysis and reduced cerebral oxygen transport in human cerebral malaria. Lancet 2, 534-537. doi: 10.1016/S0140-6736(88)92658-X

Wassmer, S. C., Combes, V., Candal, F. J., Juhan-Vague, I., and Grau, G. E. (2006a). Platelets potentiate brain endothelial alterations induced by Plasmodium falciparum. Infect. Immun. 74, 645-653. doi: 10.1128/IAI.74.1.645-653.2006

Wassmer, S. C., de Souza, J. B., Frere, C., Candal, F. J., Juhan-Vague, I., and Grau, G. E. (2006b). TGF-betal released from activated platelets can induce TNF-stimulated human brain endothelium apoptosis: a new mechanism for microvascular lesion during cerebral malaria. J. Immunol. 176, 1180-1184. doi: 10.4049/jimmunol.176.2.1180

Wassmer, S. C., Lepolard, C., Traore, B., Pouvelle, B., Gysin, J., and Grau, G. E. (2004). Platelets reorient Plasmodium falciparum-infected erythrocyte cytoadhesion to activated endothelial cells. J. Infect. Dis. 189, 180-189. doi: $10.1086 / 380761$

Weiser, S., Miu, J., Ball, H. J., and Hunt, N. H. (2007). Interferon-gamma synergises with tumour necrosis factor and lymphotoxin-alpha to enhance the mRNA and protein expression of adhesion molecules in mouse brain endothelial cells. Cytokine 37, 84-91. doi: 10.1016/j.cyto.2007.02.021

White, N. J., Turner, G. D., Day, N. P., and Dondorp, A. M. (2013). Lethal malaria: Marchiafava and Bignami were right. J. Infect. Dis. 208, 192-198. doi: 10.1093/infdis/jit116

White, N. J., Warrell, D. A., Looareesuwan, S., Chanthavanich, P., Phillips, R. E., and Pongpaew, P. (1985). Pathophysiological and prognostic significance of cerebrospinal-fluid lactate in cerebral malaria. Lancet 1, 776-778. doi: 10.1016/S0140-6736(85)91445-X

White, V. A., Lewallen, S., Beare, N. A., Molyneux, M. E., and Taylor, T. E. (2009). Retinal pathology of pediatric cerebral malaria in Malawi. PLoS ONE 4:e4317. doi: 10.1371/journal.pone.0004317

White, V. A., Lewallen, S., Beare, N., Kayira, K., Carr, R. A., and Taylor, T. E. (2001). Correlation of retinal haemorrhages with brain haemorrhages in children dying of cerebral malaria in Malawi. Trans. R. Soc. Trop. Med. Hyg. 95, 618-621. doi: 10.1016/S0035-9203(01)90097-5

Wilson, N., Driss, A., Solomon, W., Dickinson-Copeland, C., Salifu, H., Jain, V., et al. (2013). CXCL10 gene promoter polymorphism $-1447 \mathrm{~A}>\mathrm{G}$ correlates with plasma CXCL10 levels and is associated with male susceptibility to cerebral malaria. PLOS ONE 8:e81329. doi: 10.1371/journal.pone. 0081329

Yanez, D. M., Manning, D. D., Cooley, A. J., Weidanz, W. P., and Van der Heyde, H. C. (1996). Participation of lymphocyte subpopulations in the pathogenesis of experimental murine cerebral malaria. J. Immunol. 157, 1620-1624.

Conflict of Interest Statement: The authors declare that the research was conducted in the absence of any commercial or financial relationships that could be construed as a potential conflict of interest.

Received: 30 June 2014; accepted: 30 July 2014; published online: 15 August 2014. Citation: Hunt NH, Ball HJ, Hansen AM, Khaw LT, Guo J, Bakmiwewa S, Mitchell AJ, Combes V and Grau GER (2014) Cerebral malaria: gamma-interferon redux. Front. Cell. Infect. Microbiol. 4:113. doi: 10.3389/fcimb.2014.00113

This article was submitted to the journal Frontiers in Cellular and Infection Microbiology.

Copyright (C) 2014 Hunt, Ball, Hansen, Khaw, Guo, Bakmiwewa, Mitchell, Combes and Grau. This is an open-access article distributed under the terms of the Creative Commons Attribution License (CC BY). The use, distribution or reproduction in other forums is permitted, provided the original author(s) or licensor are credited and that the original publication in this journal is cited, in accordance with accepted academic practice. No use, distribution or reproduction is permitted which does not comply with these terms. 